\title{
De las grecas a las bóvedas de crucería del siglo XVI, técnicas de construcción y de cantería de los pueblos indígenas de México
}

\author{
From Stone Fretwork to Ribbed Vaults, Sixteenth-century \\ Masonry Construction Techniques of the Mexican \\ Indigenous People \\ B. Ibarra-Sevilla ${ }^{(*)}$
}

RESUMEN

Este texto pretende mostrar cómo los indígenas de México aprendieron las técnicas para construir estructuras de mampostería como arcos y bóvedas. El hilo conductor de este trabajo parte de la observación de ilustraciones del Códice Florentino, después refleja las habilidades albañiles prehispánicos observando las soluciones de construcción en el sitio de Mitla, y finalmente toma la experiencia de la reconstrucción de la bóveda de la capilla abierta de Teposcolula como caso de estudio. El tejido de estos tres componentes revela que los métodos de enseñanza de las técnicas de construcción en el siglo XVI se hicieron a través del ejemplo y del conocimiento práctico.

970-7

Palabras clave: México; cantería; tecnología de la construcción; transferencia; sistemas abovedados; siglo XVI.

\section{SUMMARY}

This text aims to reveal how natives of Mexico learned the techniques to built masonry spanning structures such as arches and vaults. The guideline of this study starts by observing illustrations of the Florentine Codex, later it reflects on pre-Columbian masons skills by looking at the building solutions in the site of Mitla, and finally takes on the unique experience of reconstructing the ribbed vault of the open chapel of Teposcolula as case study. The weaving of these three components unveils those methods of teaching building techniques during the 16th century were done by example and practical knowledge.
Keywords: Mexico; stonecutting; building technology; transference; vaulting systems; sixteenth century. 
Los dibujos del siglo XVI que se encuentran en las páginas profusamente ilustradas de la décimo libro del Códice Florentino de fray Bernardino de Sahagún ${ }^{1}$ incluyen imágenes de los trabajadores dedicados a la construcción de edificios (1). El libro está dedicado a los "vicios y las virtudes" y explica, en pocas palabras, los las buenas y malas prácticas de los talladores de piedra, albañiles y carpinteros indígenas:

"El cantero tiene fuerzas y es recio, ligero, diestro en labrar y aderezar cualquier piedra. El buen cantero es buen official, entendido y hábil en labrar piedra, en debastar, esquinar y bender con la cuña, y hacer arcos, esculpir y labrar la piedra artificiosamente. También es su oficio trazar una casa, hacer buenos cimientos y poner esquinas, y hacer bortdadas $y$ ventanas bien hechas, y poner tabiques en su lugar. El mal cantero es flojo, labra mal y viesamente y en el hacer de las paredes no las fragua, hacelas torcidas o acostadas a una parte y corcovadas".

El texto refiere muy brevemente las actividades de cantería, describiendo superficialmente las tareas de un cantero (Figura 1). Entre los numerosos estudios centrados en la naturaleza estilística de las ilustraciones del Códice, Ellen Baird señala la importancia de la imagen en el mundo precolombino y explica cómo Sahagún utiliza esta tradición indígena de representación para ilustrar el trabajo que él coordinó (2). Gran parte de los libros del Códice Florentino contienen texto en español y náhuatl, sin embargo, Baird da cuenta de que en varias partes de los libros Sahagún remplaza con dibujos el espacio que debía ocupar el texto en español. En otras palabras, el texto en español fue suplantado por los dibujos, que, en esencia, se convierten en el texto. Baird también sugiere que la función de los dibujos es para proporcionar información verbal y no para "adornar" el texto. Kevin Terraciano explica cómo la historia de principios del siglo XVI se basa casi por completo en forma gráfica y también señala cómo Fray Francisco de Burgos, cronista dominico del siglo XVII reconoce el carácter histórico de las comunicaciones pictográficas indígenas (3).

Los artistas indígenas que ayudaron a Sahagún con las ilustraciones del libro utilizaron diferentes entornos para representar las interacciones y actividades que ocurrieron durante los primeros momentos del virreinato, siendo muchos de ellos en zonas urbanas o dentro de edificios. La Figura 2 de este texto está incluida en el apartado del "cantero" del códice. En esta figura nos damos cuenta de que el artista
IThe sixteenth-century drawings found in the profusely illustrated pages of the $10^{\text {th }}$ book of the Florentine Codex by Fray Bernardino de Sahagún ${ }^{1}$ include few pictures of workers dedicated to building construction (1). The book is dedicated to vices and virtues and explains in few words good and bad practices of indigenous stone carvers and masons:

"El cantero tiene fuerzas y es recio, ligero, diestro en labrar y aderezar cualquier piedra. El buen cantero es buen official, entendido y hábil en labrar piedra, en debastar, esquinar y bender con la cuña, y hacer arcos, esculpir y labrar la piedra artificiosamente. También es su oficio trazar una casa, hacer buenos cimientos y poner esquinas, y hacer bortdadas $y$ ventanas bien hechas, y poner tabiques en su lugar. El mal cantero es flojo, labra mal y viesamente y en el hacer de las paredes no las fragua, hacelas torcidas o acostadas a una parte y corcovadas".

The very short text referring to stonecutting activities only describes the tasks in which a "cantero" (stone mason) was involved (Figure 1). Among numerous studies focused on the stylistic nature of the Codex illustrations Ellen Baird points out the relevance of the image for the pre-Columbian world and how Sahagún uses this indigenous tradition of depiction to illustrate the work he coordinated (2). Large part of the Florentine Codex books contain text in Spanish and Nahuatl, nevertheless Baird notices that in several portions of the books Sahagún dismisses the subject matter filling with drawings the space that the Spanish text was supposed to occupy. In other words, the Spanish text was supplanted by the drawings, which in essence become the text. Baird also suggests that the function of the drawings is to provide verbal information and not to adorn verbal text. Kevin Terraciano explains how the history of early sixteenth century relies almost entirely in pictorial form an points out how Fray Francisco de Burgos, a Dominican chronicler of the $17^{\text {th }}$ century recognized the historic character of the native pictographic communications (3).

The indigenous artists helping Sahagún with the book's illustrations used different locations to depict the reciprocal interactions and activities occurred during early moments of the vice-kingdom, being many of them in urban settings or within buildings. The Figure 2 in this text is included within the "cantero" paragraph in the Codex. In this image we notice that the artist chose a landscape as background representing a stone quarry dominating this landscape 


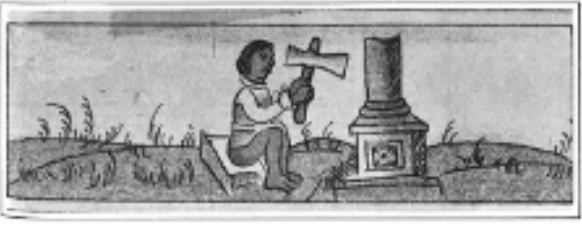

eligió un paisaje de fondo que representa banco de cantera dominando este paisaje donde pocos trabajadores desarrollan sus actividades de talla utilizando diferentes herramientas. Palos largos sirven como ayuda para los trabajadores indígenas que liberan las rocas de la colina. El artista que trabajó en esta ilustración muestra bordes afilados en las colinas que rodean con prismas casi geométricos, sugiriendo una cantera que ha sido explotada intensamente $y$ tal vez, por un número de años. El centro de la imagen muestra un par de canteros mexicanos, ambos vistiendo faldas cortas y ambos utilizando herramientas de trabajo, notamos que estos dos canteros se dedican a la talla de lo que parece ser trozos regulares de piedra. Pequeñas rocas redondeadas están esparcidas en el lugar, representando el sistema comúnmente utilizado para rodar grandes piezas de piedra con el fin de moverlas de un lugar a otro. El primer plano de la imagen es de especial interés, ya que representa a dos canteros realizando tareas de cantería, las piezas que están taIlando parecen estar finamente terminadas y seguramente serán colocadas dentro de un edificio. Centrándose en las dos figuras al frente del dibujo nos damos cuenta de que están vestidos de blanco, a la izquierda encontramos un cantero que es similar al del resto de los personajes en el dibujo, lo que sugiere que es un cantero indígena. Por lo contrario, a la derecha encontramos un cantero cuyas características físicas sugieren algo diferente. Este cantero lleva camisa de manga larga, pantalones y un sombrero similar al traje del cacique indígena "Don Domingo" dibujado en el Códice de Yanhuitlán, que Terraciano identifica como piezas de ropa española (3, pp 32-33). Mirando con atención este singular personaje también podemos identificar que es un cantero tallando una piedra más refinada y con herramientas especiales, mientras que los otros canteros de la imagen están realizando actividades más rudimentarias. ¿Porqué fue que el artista que ayudó a Sahagún retrato a este hombre de una manera diferente? ¿Era diferente a los albañiles indígenas? ¿Qué revela este dibujo sobre la transferencia de tecnología desde España a México?

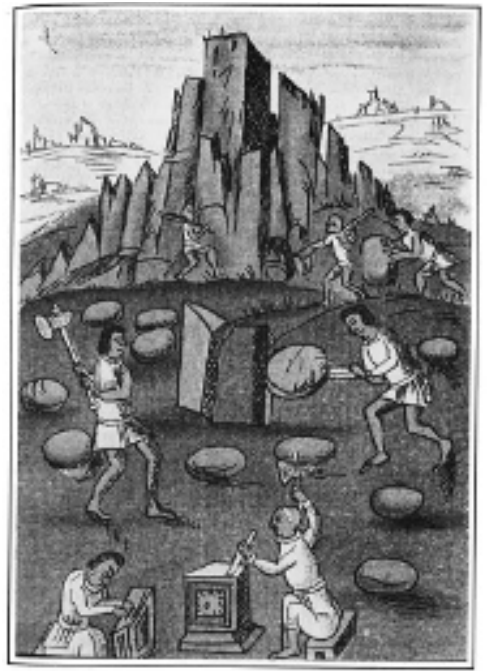

1. Imagen de indígena mexicano labrando la base de una columna. Códice Florentino de Bernardino de Sahagún siglo XVI.

1. Image of an indigenous mason carving a column base. Image from the sixteenth-century Florentino Codex by Bernardino de Sahagún.

2. Imagen de indígenas mexicanos participando en las tareas de extracción y labrado de piedra. Códice Florentino de Bernardino de Sahagún siglo XVI.

2. Image of the indigenous people involved in construction tasks. Image from the sixteenthcentury Florentino Codex by Bernardino de Sahagún. where few workers are developing their carving activities using different tools. Long sticks serve as tools for the indigenous workers to release rocks from the hill. The artist working on this illustration shows sharp edges on the surrounding hills creating almost geometric prisms and suggesting a quarry that has been exploited intensively and perhaps, for a number of years. The center of the image illustrates a couple of Mexican masons, both wearing short skirts and both using working tools. These two masons are engaged in the carving of what seems to be regular pieces of stone. Rounded small rocks are sparse all over the place depicting the system commonly used to roll down large pieces of stone in order to move them from one place to another. The foreground of the image is of special interest because it depicts two masons performing stonecutting tasks. The pieces they are carving seem to be finely finished and surely the pieces are fashioned to be placed within a building. Focusing on the two figures on the front we notice that they are dressed in white; on the left we found a mason who is similar to the rest of the characters in the drawing suggesting that he is an indigenous mason. On the right we find a mason whose physical characteristics suggest something different. This mason is wearing long sleeve shirt, pants and a hat similar to the outfit of the indigenous cacique "Don Domingo" drawn in the Yanhuitlan Codex, which are identified by Terraciano as pieces of Spanish garment (3, pp 32-33). Looking carefully to this unique character depicted in the illustration we can also identify that he is a mason is carving a stone with tools while the other characters in the picture are performing more rudimentary activities. Why did the artist helping Sahagún portrait this man in a different manner? Was he different to the indigenous masons? What does this drawing reveal about the transference of technology from Spain to Mexico? 


\section{HABILIDADES DE INDÍGENAS MEXICANOS EN TALLA DE PIEDRA Y LA CONSTRUCCIÓN MONUMENTAL}

La segunda mitad del siglo XVI trajo grandes cambios a las comunidades indígenas de México. El virreinato español trajo el cristianismo y los templos fueron construidos para dar cabida a miles que se convertían a la nueva religión. Los nuevos edificios incluían bóvedas de mampostería y la mano de obra disponible no estaba familiarizada con la geometría práctica necesaria para lograr este tipo de estructuras. Sin embargo, en un complejo proceso de simbiosis y transferencia de tecnología, constructores indígenas utilizaron los métodos más avanzados de su tiempo ayudados de su conocimiento de los materiales de construcción disponibles localmente y trabajaron con maestros de obras venidos de Europa para construir piezas de arquitectura monumental. Para los maestros españoles fue crucial saber dónde encontrar trabajadores calificados para el tipo de trabajo que les encargaban los frailes, de esto dependía lograr sus objetivos y su éxito estribaba en la capacidad para adaptarse y manejar las nuevas circunstancias del virreinato. Estas circunstancias eran obviamente muy diferentes a las de España y los precedentes de arquitectura monumental y mano de obra precolombina fueron claves para desarroIlar los nuevos edificios.

Para ilustrar la habilidad de los indígenas mexicanos en talla de piedra y construcción con mampostería me gustaría utilizar como ejemplo el sitio precolombino de Mitla (100-1521 DC) que esta cerca de la ciudad de Oaxaca (Figura 3). Dado que los documentos históricos sobre el trabajo de los canteros y sus habilidades de talla son inexistentes, edificios monumentales como Mitla se convierten en la evidencia de que previo al virreinato se lograron tareas de construcción complejas en diferentes regiones en todo el territorio mexicano. Aunque modestos en escala, los edificios de Mitla son notables por su excepcional trabajo de cantería. A Mitla se le menciona muy a menudo como una de las obras más refinadas de la arquitectura construida en Mesoamérica. La ornamentación en los muros de los edificios de Mitla está hecha con un intricado juego de grecas tallados con delicadas pequeñas piezas de piedra tallada. Este complejo arquitectónico puede ser el mejor ejemplo para identificar la presencia de mano de obra con experiencia en la construcción en la región de Oaxaca y es testimonio de la realización de grandes proyectos de construcción de culturas de la región.

\section{MEXICAN SKILLS IN STONE CARVING AND MONUMENTAL CONSTRUCTION}

The second half of the $16^{\text {th }}$ century brought tremendous changes to the indigenous communities of Mexico. Colonization by Spain brought Christianity to the area, and church buildings were built to accommodate thousands converting to the new religion. The new buildings included masonry vaults and the available workforce was not familiar with the practical geometry necessary to achieve such structures. However, in a complex process of symbiosis and cultural transfer, indigenous masons, using the most advanced technology of their time and their deep knowledge of locally-available building materials, worked with Spanish master builder. Knowing where the skilled workers were and the type of work that they were capable of accomplishing was crucial to those Spanish master builders whose commissions had to be accomplished using the local labor. Their success depended on their ability to adapt and manage the new circumstances of the colony. Those circumstances were very different to those in Spain. The precedents of labor-intensive endeavors of the preColumbian monumental architecture were key to develop the new buildings.

In order to illustrate the indigenous skills on stone carving and masonry construction, I would like to use as example the preColumbian site of Mitla (100-1521 AC) near the city of Oaxaca (Figure 3). Since historic documents regarding stonemasons and their actual carving skills are no existent, monumental buildings such as Mitla become the evidence that complex construction tasks were achieved in different regions across the Mexican territory. Although modest in scale, this group of buildings is notable for their outstanding stonework. Mitla is often referred as one of the most refined works of architecture built in Mesoamerica. The wall ornamentation of Mitla's buildings is based on intricate patterns made with delicately carved, small pieces of stone. This city is the best example to identify the presence of experienced labor-intensive building construction in the region of Oaxaca and testimony of experience in carrying out large construction projects by cultures of the region.

The abilities necessary to achieve the level of construction refinement found in Mitla's buildings belong to well-trained masons who were able to make an efficient use of the rudimentary stone tools available at the 
Las habilidades necesarias para alcanzar el nivel de refinamiento de la construcción que se encuentra en los edificios de Mitla pertenecen a canteros bien entrenados que fueron capaces de hacer un uso eficiente de las rudimentarias herramientas de piedra disponibles en el momento. Además de la talla refinada de piedra, los edificios incluyen soluciones constructivas sólidas. Observando estos edificios con detalle se pueden encontrar las estrategias de construcción destinadas a garantizar su estabilidad dentro de la zona sísmica en la que se construyeron. Las piezas de esquina y sillares en los muros están tallados y colocados para mantener la resistencia estructural insertados en las gruesas paredes evitando en los despieces juntas verticales continuas. Esta conformación anisótropa de las paredes de Mitla (Figura 4) era común en todo México precolombino y es muy similar a la conformación de pared presentado por el profesor Santiago Huerta en sus estudio de edificios Europeos (4).

Lo que ha sorprendido a muchos estudiosos de los edificios de Mitla es el tamaño de los grandes trozos de piedra que se usaron para las columnas y dinteles. La obra del arqueólogo y arquitecto William Holmes es quizás el análisis más completo realizado a estas estructuras mostrando los sistemas constructivos empleados en los edificios (5). Ignacio Marquina, en su libro sobre la arquitectura prehispánica explica cómo las columnas son de aproximadamente 5 metros de altura y $90 \mathrm{~cm}$ de diámetro, mientras que los dinteles alcanzan $3,8 \mathrm{~m} \times 1,95 \mathrm{~m} \times$ $0,60 \mathrm{~m}$ pesando entre 10 y 15 toneladas (6), siguiendo una secuencia lógica de la construcción, se puede reconocer que estas piezas de piedra caliza primero tenían que ser obtenidas en el banco de cantera y más tarde, cuidadosamente transportados al sitio de construcción. La arqueóloga Nelly Robles ha encontrado la cantera de donde se obtuvo la piedra y muestra el registro time. In addition to refined stone carving, the buildings include solid constructive solutions. By observing these buildings with detail, one can find construction strategies aiming at ensuring the buildings' stability within the seismic zone in which they were built. Wall corner pieces and ashlars are carved and placed to maintain structural strength along with thick walls and careful coursing that avoids continuous vertical joints. This anisotropic conformation of the walls of Mitla (Figure 4) was common throughout pre-Columbian Mexico and it is very similar to the wall conformation presented by Santiago Huerta in his study of masonry structures built in Europe (4).

What has amazed many scholars studying Mitla's buildings is that they feature large pieces of stone that were used as columns and lintels. The work of the architect and archeologist William Holmes is perhaps the most complete analysis done to these structures (5). Ignacio Marquina, in his book on pre-Columbian architecture explains how columns are approximately $5 \mathrm{~m}$ tall and $90 \mathrm{~cm}$ in diameter, while lintels reach $3.8 \mathrm{~m} \times 1.95 \mathrm{~m} \times 0.60 \mathrm{~m}$ weighting 10 to 15 tons (6,) Following a logical sequence of construction, one can recognize that these limestone pieces had to first be obtained from the quarry and later, carefully transported to the construction site. The archeologist Nelly Robles has found the quarry where the stone was obtained and registered some of the rudimentary carving tools made of stone spread out in the site (7). Since the use of the wheel for transportation purposes in the pre-Columbian world is still under debate, one can assume that a cautious dragging procedure was implemented for the transportation of these large stone pieces. As part of the construction process, the large columns and lintels were to be placed in the correct position within the building, implying a forceful labor necessary to accomplish
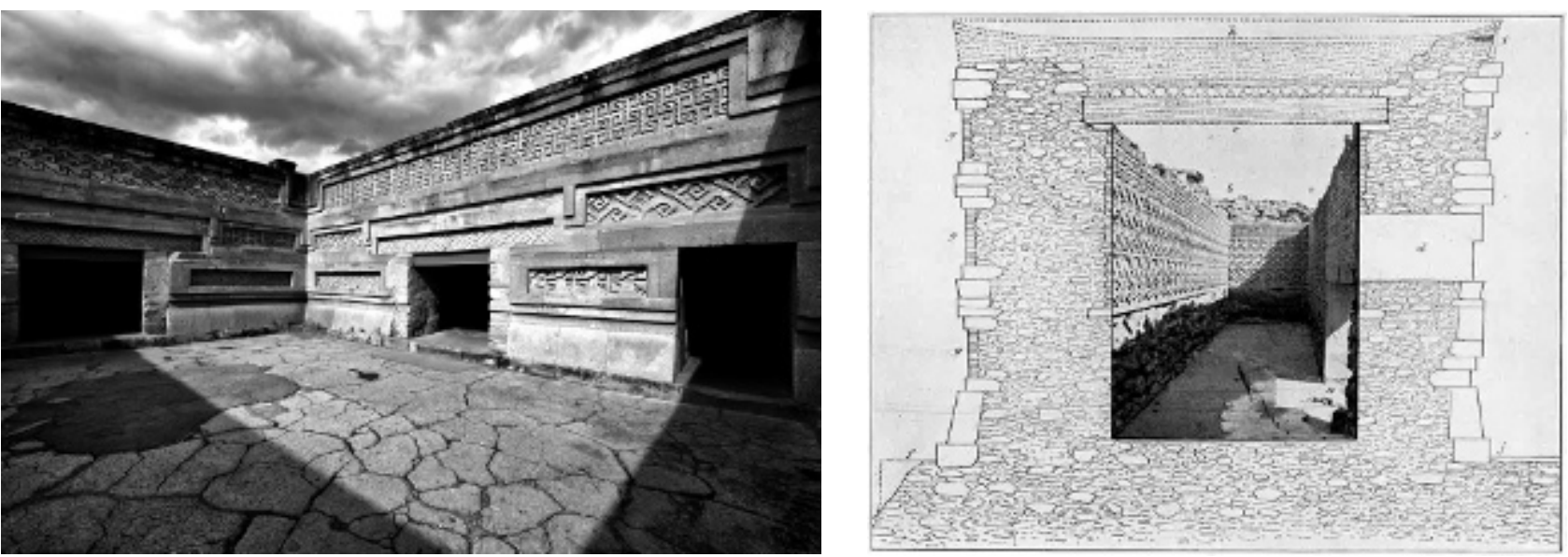

3. El patio del palacio de las Columnas construido en el siglo XV en Mitla, Oaxaca, México.

3. The courtyard of the columns palace in Mitla built in the fifteenth century, Oaxaca, México.

4. Habitación en el palacio de las columnas de Mitla en Oaxaca, México. Dibujo W. Holmes. (7, p. 261).

4. Room of the palace of Mitla in Oaxaca, Mexico. Drawing by W. Holmes. (7, p. 261). 
de rudimentarias herramientas de talla de piedra esparcidas en el sitio (7). Dado que el uso de la rueda para fines de transporte en el mundo precolombino sigue siendo objeto de debate, se puede suponer que un cauteloso procedimiento de arrastre se implementó para el transporte de estas grandes piezas de piedra. Como parte del proceso de construcción, las grandes columnas y dinteles debieron ser colocadas en la posición correcta dentro del edificio, lo que implica un trabajo extraordinario necesario para realizar esta tarea basada en la fuerza física. No hay documentación de las herramientas o equipo utilizado para levantar y colocar grandes trozos de piedra, ni de cómo se logró esta parte del proceso de construcción sin el uso de grúas. Sin embargo, cualquier persona con experiencia en la construcción de mampostería puede deducir que las actividades realizadas para mover y colocar estos enormes pedazos de piedra deben haber seguido una secuencia lógica que exige la aplicación de estratégicos medios y métodos al momento en que los edificios fueron erigidos.

Otro caso de construcción de muros se encuentra los edificios y el puente de San Miguel Tequixtepec del siglo XVI que muestran cómo se disponían las piezas de piedra para formar los muros de los edificios tradicionales precolombinos. Los albañiles de la región mixteca utilizaron una técnica constructiva que permitía usar piedra de tamaños diversos que se establecían al azar, formando al colocarlas un mosaico de piedra (Figura 5). Estos constructores indígenas no tenían como objetivo formar hiladas horizontales de piedra, las razones detrás de este tipo de construcción indígena hecha con sillares rectangulares de distintas dimensiones se relacionaba con el proceso de construcción más que con valores estéticos. En la obtención de piedra cantera las piezas no suelen tener dimensiones iguales, por lo tanto, este modo de disponer la sillería se adoptó para maximizar el uso de la piedra extraída. Aunque es muy eficiente en la utilización del material, esta solución de sillería también tenía sus propias complejidades pues los sillares en ocasiones tenían que ser extremadamente pequeños con el fin de llenar los espacios minúsculos que dejan las piedras más grandes.

Las columnas de los edificios mesoamericanos eran cortas en comparación con los europeos. Las columnas en México pueden ser de una sola pieza de piedra o segmentos que se apilan hasta completar un fuste ( $\mathrm{Fi}-$ gura 6). Otros sitios como Yagul (500-1521 DC) Monte Albán (500 AC-1000 DC), que fueron construidos antes de Mitla muestran columnas conformadas de manera similar this task. There is no documentation of the tools or equipment used to lift and place large pieces of stone, neither of how this this part of the construction process was achieved without the use of cranes. However, anyone with some experience in masonry construction might deduce that the activities undertaken to move and place these enormous pieces of stone must have followed a logical sequence necessitating the implementation of strategic means and methods as buildings were erected.

Another particular example of wall construction is found in the sixteenthcentury buildings and bridge of San Miguel Tequixtepec which show how traditional pre-Columbian buildings use stone to form walls. The masons of this Mixtec region used a constructive technique allowing for various sized pieces of stone to be laid randomly, forming a mosaic of stone (Figure 5). These indigenous masons did not aim to form horizontal rows of stone as their counterparts did in Europe. The reasons behind this indigenous type of coursing made with rectangular ashlars of various dimensions were related to the construction process rather than aesthetic values. When obtaining stone from the quarry the pieces rarely have similar dimensions, therefore this mode of ashlar arrangement was adopted to maximize the usage of extracted stone. Although very efficient in material utilization, this ashlar solution also had its own intricacies. The ashlars at times were required to be extremely small in order to fill in the minuscule spaces left by larger stones, making the carving of these small pieces a very delicate process.

The columns of the Mesoamerican buildings were short in comparison with European buildings. The columns are either single pieces of stone that would be inserted within the floor or segments that are stacked up to complete a shaft (Figure 6). Other sites such as Yagul (1250-1521) and Monte Alban (500 BC-1000 AC), which were built before Mitla show columns conformed similarly to walls, i.e. with ashlars in the perimeter and core made of rubble and mud. The Mayans of the Yucatan peninsula divided the column's shaft in smaller pieces. Columns of this nature can be found in the site of Chichen Itza (600-1200 AC). Mitla's builders on the contrary, used one single stone to complete the columns. Nevertheless, it is important to highlight here that Mesoamerican architecture is not characterized by the use of columns.

A few of the buildings in Mesoamerica were under construction at the moment of the Spanish arrival. One may consider that the 
a las paredes, es decir, con sillares en la superficie y núcleo hecho de escombros y lodo. Los mayas de la península de Yucatán dividían el fuste de la columna en pedazos más pequeños y columnas hechas de esta forma se pueden encontrar en el sitio de Chichén Itzá (600-1200 DC). Constructores de Mitla, por el contrario, utilizan una sola piedra para completar las columnas. Sin embargo, es importante destacar aquí que la arquitectura mesoamericana no se caracteriza por el uso de columnas.

Algunos de los edificios de Mesoamérica estaban en construcción en el momento de la llegada de los españoles. Se puede considerar que las habilidades para la explotación de canteras y la talla de sillares y dinteles eran conocimiento común de los canteros indígenas. Por lo tanto, los maestros constructores de los monasterios y palacios reclutaron canteros de todo México para ayudar con los esfuerzos de construcción de los edificios monumentales y las nuevas ciudades. Es importante considerar que aunque las prácticas del tallado de piedra en Mesoamérica eran muy refinadas, nunca se aplicaron a la construcción de arcos y bóvedas. La formación y la contratación de indígenas para tallar piezas de piedra y construir estas estructuras debieron haber presentado un desafío para los españoles, la mano de obra requerida tenía que estar calificada y la capacitación de indígenas fue crucial para lograr los objetivos.

\section{LOS EDIFICIOS NUEVOS Y LA TRANSFORMACIÓN DEL ENTORNO CONSTRUIDO}

La transformación física del entorno construido se llevó a cabo en gran medida en dos etapas. Inmediatamente después de la llegada de los españoles a la región en la década de 1530, la tarea principal era desmontar los templos precolombinos reutilizando la piedra para la construcción de los nuevos edificios. Esta primera fase cambió la fisonomía de los pueblos por la superpo- skills visible in quarrying and carving ashlars and lintels were common knowledge of the indigenous masons involved in the construction of those buildings. Thus, the master builders of monasteries and palaces recruited masons from all over Mexico to assist with the construction endeavors of the monumental constructions. It is important to consider that although stonecarving practices in Mesoamerica were very refined, they were not applied to construct arches and vaults. Training and recruiting indigenous people to carve pieces of stone for these structural elements should have presented a challenge for the colonizers. These new construction endeavors required a more skilled labor force and educating the indigenous people was crucial to accomplish the goals.

\section{NEW BUILDINGS AND TRANSFORMATION OF THE BUILT ENVIRONMENT}

The physical transformation of the built environment took place largely in two stages. Immediately after the Spanish arrival to the region in decade of the 1530s, the main task was to disassemble the preColumbian temples reusing the stone to construct the colonizers new buildings. This first phase changed the physiognomy of the original towns by superimposing the new buildings onto the indigenous structures. These indigenous monuments were dismantled and/or reconfigured to create Christian churches, Spanish palaces, and administrative buildings (8). The open spaces were also modified according to western traditions. The transformation of the iconic buildings signified the superposition of the new social and religious order. This exercise of demolition, reuse and construction was common in Europe, especially in Spain where practices of rehabilitation and adaptation of many Arab buildings to new uses was common. The practice of using, recycling would be a methodic experience in the
5. Sillares de las paredes en el puente del siglo XVI de San Miguel Tequixtepec en Oaxaca México. El símbolo indígena del año se puede distinguir en la superficie de la pared.

5. Ashlars of the walls in the sixteenth-century bridge of San Miguel Tequixtepec in Oaxaca, Mexico. The indigenous symbol of year can be distinguished on the surface of the wall.

6. Sección del palacio de las columnas de Mitla. Dibujo por W. Holmes. (7, p. 261).

6. Section through the columns palace of Mitla in Oaxaca, Mexico. Drawing by W. Holmes. (7, p. 261).
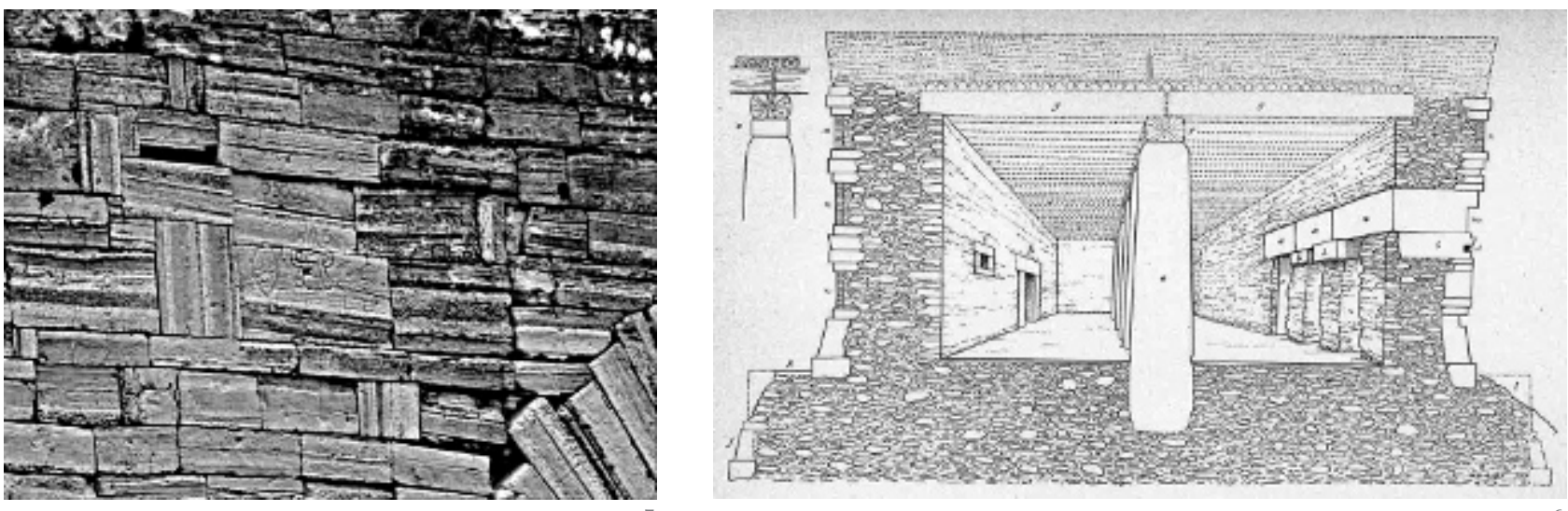
sición de nuevos edificios sobre las estructuras indígenas. Los monumentos indígenas fueron desmantelados o reconfigurados para crear iglesias cristianas, los palacios españoles, y edificios administrativos (8). Los espacios abiertos también fueron modificados de acuerdo a las tradiciones occidentales. La transformación de los edificios emblemáticos significó la superposición de un nuevo orden social y religioso. Este ejercicio de demolición, la reutilización y construcción era común en Europa, especialmente en España donde se practico la rehabilitación y adaptación de muchos edificios árabes a los nuevos usos. La práctica de usar, reciclar se iba experimentando casi metódicamente en la península ibérica a través de la reocupación católica de los territorios del sur. Por lo tanto, las condiciones que se presentaron en México durante el siglo XVI sólo representaban una continuación de las estrategias de conversión que tuvieron lugar en la península Ibérica durante los siglos anteriores.

La segunda fase comenzó cuando se abandonaron algunos de los asentamientos originales y toda la comunidad se trasladó a lugares cercanos. Estos cambios fueron promovidos por los españoles y autorizadas por el Virrey en el segundo tercio del siglo XVI (9). La justificación para reubicar comunidades se basó en gran medida a saneamiento, es muy probable que las epidemias influenciaron estas decisiones. Las ciudades originales se convirtieron en grandes cementerios después de la gran epidemia de 1576, que disminuyó considerablemente la población (10). Estas nuevas comunidades crearon condiciones de tabula rasa para la construcción y abrieron oportunidades para el diseño de nuevos arquetipos que expresaran la modernidad de la época. Como menciona el profesor José Miguel López Villalba -el urbanismo de la ciudad nueva no debía ser solamente un lugar para vivir sino el arquetipo del futuro- (11). Esta oportunidad de nuevas ciudades se vio ligada a las ordenanzas venidas de España, aun cuando Felipe II hace el compendio hasta 1573 , es sabido que las instrucciones de fecha 26 de junio de 1523 recibidas por Cortés ya disponían los espacios de una ciudad en forma similar a la estipulada en las ordenanzas. Es necesario aquí mencionar que estas instrucciones ya dejaban ver la notoria influencia de lecturas de Vitruvio, Santo Tomás de Aquino y otros teóricos europeos de la urbanística del renacimiento (12).

Nuevos monasterios e iglesias se desarroIlaron en todo el territorio mexicano, los diseños de las nuevas ciudades se basaron en retículas que siguieron los puntos cardi-
Iberian Peninsula throughout the Catholic reoccupation of the southern territories. As such, the conditions that arose in Mexico during the sixteenth century simply represented a continuation of the strategies of conversion that took place in the Iberian Peninsula over previous centuries.

The second phase began when some of the original settlements were abandoned and entire communities relocated to nearby sites. These changes were promoted by the Spaniards and authorized by the Viceroy in the second third of the sixteenth century (9). The justification to relocate communities was based largely on sanitation; it is very likely that epidemics were part of these decisions. The original cities became large burial sites after a great epidemic of 1576, which diminished the population considerably (10). These new communities created tabula rasa conditions for construction opening up opportunities for the design of new archetypes that expressed the modernity of the time. As noted by Professor José Miguel López Villalba -the new city planning should not only be a place to live but the archetype of the future- (11). This opportunity of new cities was linked to "las ordenanzas" coming from Europe, even when Philip II makes the compendium in 1573, it is known that the instructions received by Cortés dated on June 26, 1523, already had city spaces similar to those contained in "las ordenanzas." It is necessary here to mention that these instructions let see the notorious influence of Vitruvius readings, St. Thomas of Aquino and other European theorists of the urban renaissance (12).

New monasteries and churches were developed across the entire Mexican territory. The new towns' layouts were based on cardinal grids that included a carefully chosen location for the palaces of the local Caciques (13). Many of these archetypes were based on precedents found in Europe as the monastic complexes in these communities followed similar programmatic elements as those built in the old continent (for example the sixteenth-century "Capilla Real de Indios" in Cholula, which precedent is clearly the mosque of Cordoba). The buildings included vaulted ceilings, cloisters, and spaces suited to the inner life of the monastery (14). At early stages of the colony, the atrium of the monastic ensembles became an important component; these large man-made platforms were the space where many of the liturgical and educational activities took place (Figure 7).

The work related to construction developed during this early period of the conquest 
nales. Algunas nuevas ciudades incluyeron un lugar cuidadosamente elegido para los palacios de los caciques locales (13). Muchos de los edificios que se construyeron, como los complejos monásticos, se basaron en precedentes que se encuentran en Europa. Estos conjuntos monásticos siguieron elementos programáticos similares a los construidos en el viejo continente (por ejemplo, la "Capilla Real de Indios" en Cholula del siglo XVI cuyo precedente es claramente la mezquita de Córdoba). Algunos de los edificios incluyeron techos abovedados, claustros y espacios adaptados a la vida interior del monasterio (14). En las primeras etapas del virreinato, el atrio de los conjuntos monásticos se convirtió en un componente importante, estas grandes plataformas artificiales fueron el espacio en el que muchas de las actividades litúrgicas y educativas tuvieron lugar (Figura 7).

El trabajo relacionado con la construcción desarrollado durante este primer período de la conquista consistió en el trabajo duro, que requería de fuerza física en lugar de habilidades refinadas. Instrumentos de hierro europeos eran casi inexistentes en América, los trabajos de construcción se realizaban sobre todo con precarias herramientas de piedra con las que contaba la población indígena de México (15).

\section{RECREACIÓN DE ESCENARIOS DE TRANSFERENCIA DE TECNOLOGÍA, LA RECONSTRUCCIÓN DE LA BÓVEDA DE LA CAPILLA ABIERTA DE TEPOSCOLULA COMO CASO DE ESTUDIO}

La reconstrucción de la bóveda de la Capilla abierta de Teposcolula ha puesto de manifiesto las actividades necesarias para la construcción de una gran bóveda de crucería (Figura 8). Esta reconstrucción se llevó a cabo entre los años de 1995 y 1999 utilizando tecnología y procesos similares a los utilizados en el siglo XVI. El criterio para la intervención era utilizar la misma piedra caliza, así como volver a crear las piezas y las nervaduras para mantener la integridad física y estructural de la construcción original. Dado que la mano de obra utilizada para reconstruir la bóveda no tenía ninguna experiencia previa en este tipo de construcción (incluyendo la talla de piedra), este singular proceso ofrece aspectos claves para evaluar la forma en que ocurrió la transferencia de tecnología en el siglo XVI (16).

Las actividades involucradas en la reconstrucción de la bóveda fueron en general: la extracción de piedra, el transporte al sitio de construcción, talla de piedra, y el ensamblado de la bóveda. Estas etapas de la

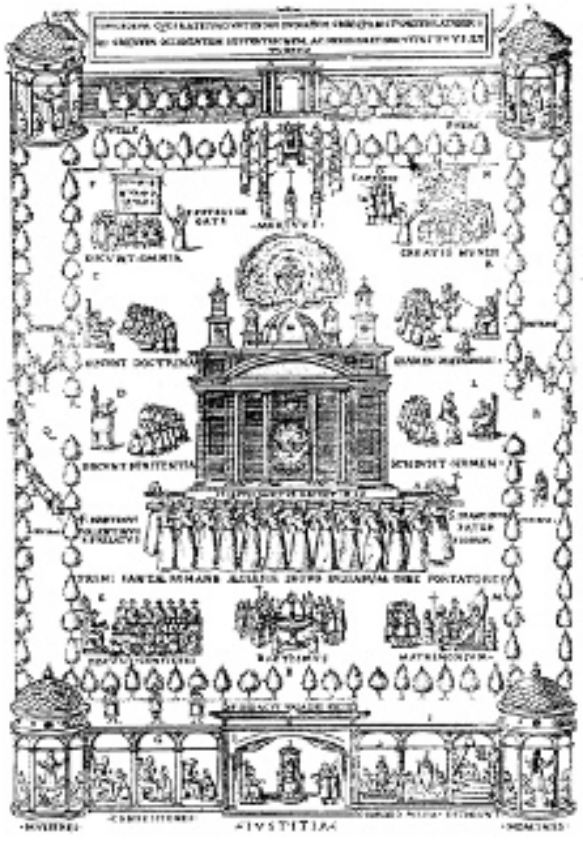

7. Atrio grabado por Fray Diego Valadés en Rethorica Christiana 1579.

7. Atrium engraving by Fray Diego Valadés in Rethorica Christiana 1579. consisted of hard labor, which required physical strength rather than refined skills. At this point in the colony, iron-made European tools were almost nonexistent in the Americas; construction work was mostly accomplished using the precarious local tools of the indigenous people of Mexico (15).

\section{RECREATION OF TECHNOLOGY TRANSFERENCE SCENARIOS, THE RECONSTRUCTION OF THE VAULT OF THE OPEN CHAPEL OF TEPOSCOLULA AS CASE STUDY}

The reconstruction of the vault of the open Chapel in Teposcolula has revealed the activities necessary to construct a large ribbed vault (Figure 8 ). This reconstruction took place between 1995 and 1999 using similar technology and processes to those utilized in the $16^{\text {th }}$ century. The criterion for the intervention was to use the same limestone as well as recreating the pieces and ribs maintaining the physical and structural integrity of the original construction. Since the labor utilized to reconstruct the vault did not have any previous experience in this type of construction (including stone carving) this unique process provides key aspects to evaluate how the transfer of technology happened during the $16^{\text {th }}$ century (16).

The activities involved in the vault's reconstruction were generally: stone extraction from the quarry, transportation to the construction site, stone carving, and vault assembling. These stages of construction required a well-organized work force. Because the quarries were in the 
8. Bóveda de la capilla abierta de Teposcolula en Oaxaca, México. Imagen después de la reconstrucción.

8. Vault of the open chapel of Teposcolula in Oaxaca, Mexico. Image after the restoration.

9. Extracción de cantera en el sitio de Yucumesa cercano a Teposcolula en Oaxaca. México.

9. Quarry at the site of Yucumesa, nearby Teposcolula in Oaxaca, Mexico.

10. Mineros extraen piedra del banco en Yucumesa, Oaxaca, México, 1996.

10. Miners extracting stone from the quarry in 1996. construcción requirieron de una fuerza de trabajo bien organizada. Debido a que las canteras estaban en el entorno de la localidad, los mineros tenían que vivir cerca o ser transportados para llegar al lugar de trabajo (Figura 9). Al igual que las ilustraciones del libro de Sahagún, los mineros utilizan palos largos y otras herramientas rudimentarias para obtener la piedra de la cantera (Figura 10). A medida que la piedra se extrae de la mina, algo de talla se hizo en el banco de cantera para hacer las piezas más pequeñas y regulares. El tamaño de la pieza siempre estuvo en función al volumen necesario para que una clave o una dovela "cupiera" dentro de la roca (Figura 11). El transporte de grandes bloques de piedra y piezas más pequeñas tomó gran esfuerzo (Figura 12).

La mayoría de la talla de las piezas de la bóveda se realizó después de la piedra llegó al sitio de construcción (Figura 13). La dificultad del labrado variaba, dependiendo del tipo de pieza (Figura 14). Además de las nervaduras, dovelas, y sillares, la bóveda se resuelve con claves para articular la intersección de las nervaduras (Figura 15). El proceso de tallado de claves necesitó de instrucciones precisas, de lo contrario la pieza no se ensamblaba correctamente dentro de la bóveda (Figura 16). Una de las premisas de este proyecto era conseguir la forma adecuada para garantizar el trabajo estructural correcto de los arcos.

Los canteros que explotaban, tallaban, y colocaban las piedras venían de una comunidad a unos $60 \mathrm{~km}$ de la ciudad de Teposcolula. Los canteros aprendieron rápidamente las antiguas técnicas de construcción. La enseñanza de cómo tallar piedra para un novato incluía primero la talla de sillares simples y otras piezas de formas regulares. Ese trabajo era relativamente conocido para la mayoría de los canteros sin mucha experiencia y, al hacer esto, los aprendices fueron capaces de entender el uso de herramientas, el dominio de los principios de la talla de piedra mientras que

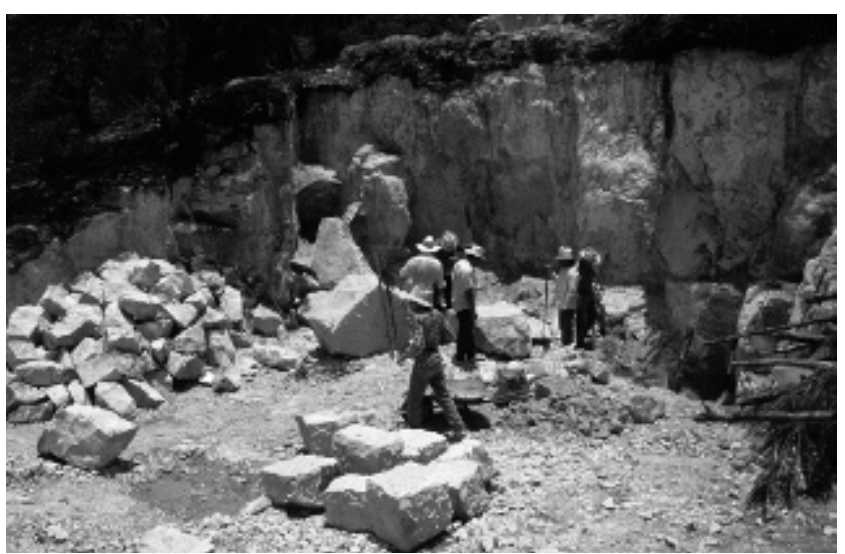

vicinity of the town, the miners had to live close by or being transported to reach the job site (Figure 9). Similar to the illustrations of Sahagún's book, the miners used long sticks and other rudimentary tools to obtain the stone from the quarry (Figure 10). As the stone was extracted from the mine, some carving was done at the quarry to make the pieces smaller and more regular, these first carving stage was done depending of the volume necessary to either fit a keystone or a voussoir (Figure 11). The transportation of large blocks of stone and smaller pieces took great effort (Figure 12).

Most of the carving of the vault's pieces was performed after the stone arrived to the construction site (Figure 13). The stonecutting difficulty varied depending on the type of pieces (Figure 14). In addition to ribs, voussoirs, and ashlars, the vault is solved with bosses articulating the intersection of ribs (Figure 15). The carving process of keystones and bosses required precise
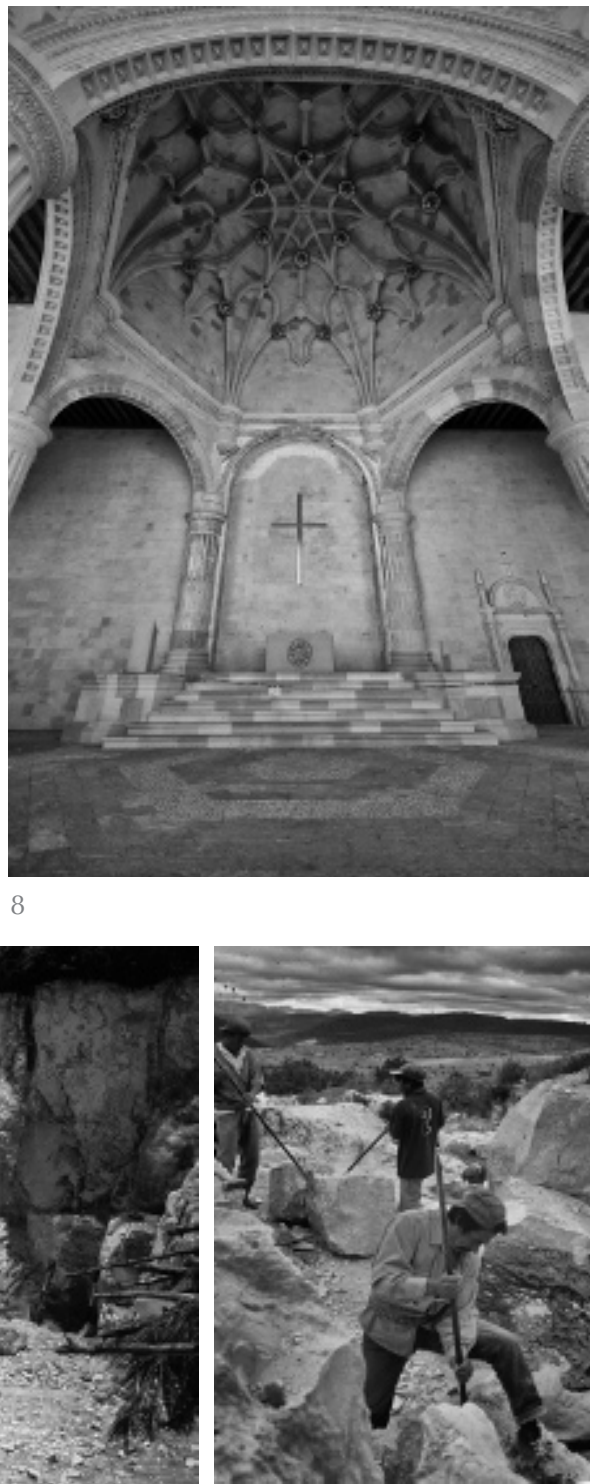

10 
comprendían la consistencia y el grano de la piedra. Más tarde, fueron asignados a tareas más complejas incluyendo el tallado de dovelas de arco que comprendía superficies curvas además de las juntas en forma de cuña. Algunos arcos, como los formeros tenían una moldura más compleja que requirió un proceso más cuidadoso. Este proceso de aprendizaje llevó unos cuantos meses hasta que el aprendiz estaba listo para llevar a cabo una tarea más compleja como el tallado de una clave. El proceso para desarrollar esta tarea más compleja consistió fundamentalmente en la imitación o el ejemplo. El maestro cantero tallaba una pieza grande y compleja bajo la estrecha supervisión de los arquitectos, y una vez que la pieza estaba terminada los otros canteros menos calificados reproducían la misma pieza varias veces hasta completar el número necesario para construir la bóveda. El proceso de talla de estas piezas más complejas se logra básicamente mediante la copia, una vez que una pieza fue tallada, otros podrían observar y seguir los detalles bajo la dirección del maestro cantero. La mayoría de las piezas siguieron un proceso lineal desde la extracción hasta la colocación de la bóveda, pero algunos otros no tuvieron el mismo final. Era inevitable que
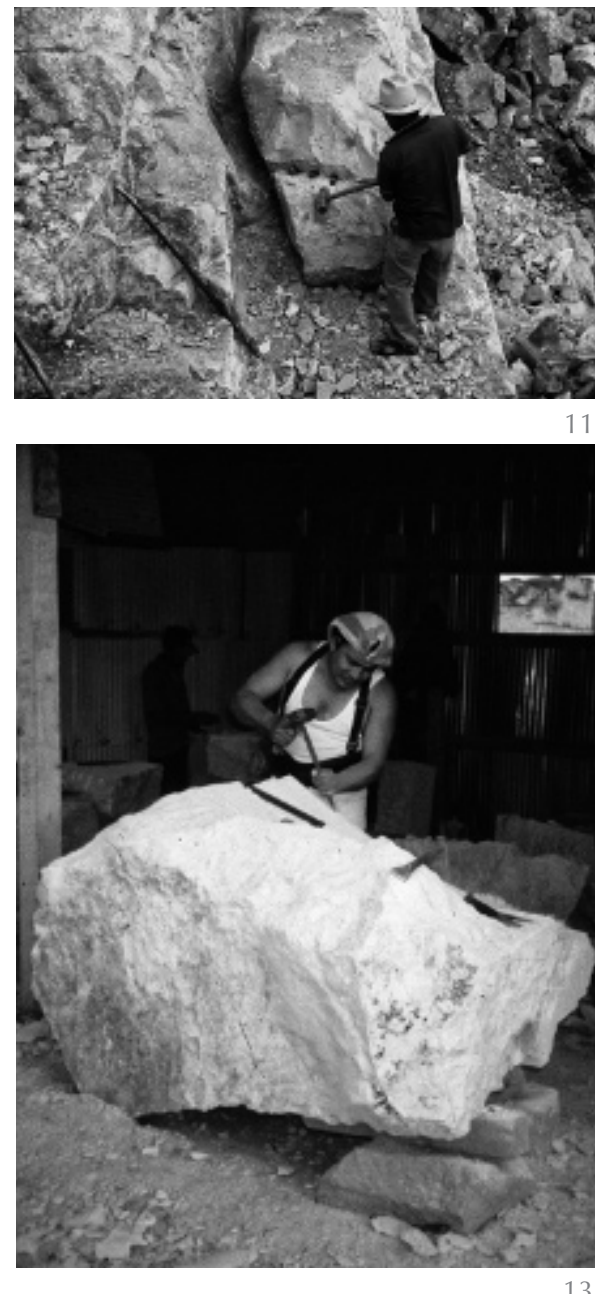

instructions; otherwise the piece would not fit correctly within the vault (Figure 16). A premise of this project was to achieve the right shape in order to guarantee the correct structural work of the arches.

The masons who exploited, carved, and placed the stones came from a community about $60 \mathrm{~km}$ from the town of Teposcolula. The masons quickly learned the ancient building techniques. The tasks involved in teaching how to carve stone to a novice mason first comprised the carving of simple ashlars and other pieces of regular shapes. That work was familiar for most of the inexperienced masons and, by doing this, the apprentices were able to understand the use of iron tools, mastering the basics of stone carving while learning about the grain of the stone. Later, they were assigned to more complex tasks, those included the carving of an arch voussoir, which comprised curved surfaces of the arch in addition to the wedge-shaped bed joints. Some arches, such as the former arches of the chapel, included complex molding, which required a more careful approach. This learning process took a few months until the apprentice was ready to accomplish a more complex assignment
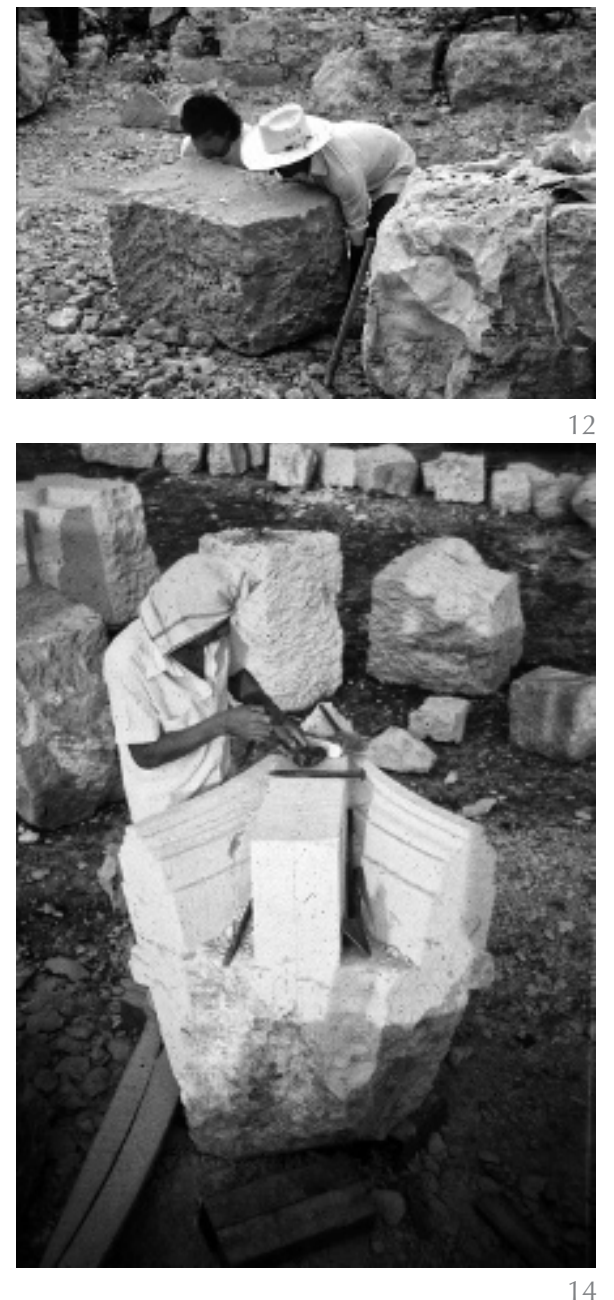

11. Cantero regularizando una pieza de piedra en Yucumesa, Oaxaca, México. 1996.

11. Miner at the quarry giving shape to a stone in 1996.

12. Mineros rodando una piedra a mano en 1996.

12. Miners rolling a stone by hand in 1996.

13. Maestro cantero tallando una piedra que llegó del banco de cantera en Teposoclula, Oaxaca, México.

13. Master stonemason carving stone as it arrived from the quarry in 1996.

14. Cantero tallando una clave para la bóveda de la capilla abierta de Teposcolula en 1997

14. Stonemason carving a vault boss in 1997. 
15. Cantero definiendo una clave para la bóveda de Teposcolula en 1997.

15. Stonemason carving a vault boss in 1997.

16. Cantero tallando una clave para la bóveda de Tepsocolula en 1997.

16. Stonemason carving a vault boss in 1997.

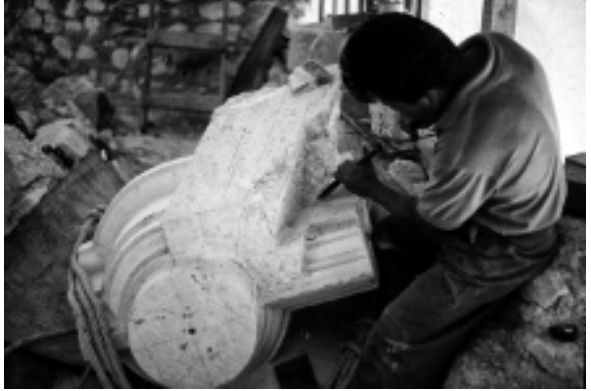
15

las piezas se rompieran en el proceso de tallado, otras tenían formaciones duras que eran imposibles de tallar y otras fueron taIladas incorrectamente. La mayor parte de estas piezas fueron reutilizadas para hacer dovelas y/o ser utilizado como escombros de relleno para muros, contrafuertes, etc.

Los procesos involucrados en este esfuerzo -inusual para el siglo XX- han puesto de manifiesto algunas de las técnicas que los maestros albañiles utilizaban para enseñar a los demás el arte de la talla de piedra. La presencia de un cantero experimentado que podía entender las operaciones necesarias para lograr las formas deseadas en piedra fue crucial para lograr la tarea. Esta experiencia reveló que la transferencia de conocimientos en el arte de la talla de la piedra se pudo haber hecho con el ejemplo. La educación de un aprendiz requiere la adquisición progresiva de habilidades como ocurre en otros gremios y disciplinas. La talla de piedras para los sistemas abovedados se basa en la geometría práctica que resulta en piezas conocidas para enjarjes, claves, intersecciones, nervaduras, y plementerías, todas ellas talladas de acuerdo con los antiguos principios de estereotomía. Ya que el proceso de labrado de piezas para bóvedas nervadas tiene que seguir con rigor las leyes que rigen el buen funcionamiento estructural de los arcos, podemos deducir que durante este proceso de enseñanza y aprendizaje que se genero durante el siglo XVI hubo muy poco espacio para la improvisación o para hacer cambios sustanciales (17).

\section{DE GRECAS A BÓVEDAS DE CRUCERÍA}

Hemos visto el proceso de la reconstrucción de la bóveda en Teposcolula, ahora debemos mirar de nuevo a la Figura 2. Esta ilustración del siglo XVI sobre los canteros representada en el códice de Sahagún muestra un escenario que tiene enormes similitudes con las situaciones observadas durante la reconstrucción de la bóveda durante el final del siglo XX. De acuerdo con la experiencia y el proceso podemos sugerir que la figura que lleva la camisa de

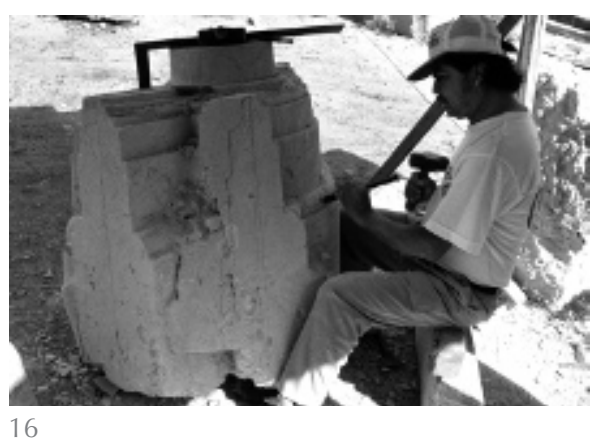

such as the carving of a ribbed vault boss. The process to develop this more-complex task consisted mostly on imitation or example. The master stonemason would carve one large and complex piece under close supervision of the architects, and once the piece was finished the less skilled masons would reproduce the same piece several times to complete the number necessary for the vault's construction. The carving process of these complex pieces was achieved basically by copying, once one piece was carved, others could observe and follow the details under the direction of the master mason. Most of the pieces followed a linear process from extracting to positioning on the vault but few others did not have the same ending. It was inevitable that pieces broke in the process of carving, some others had hard formations that were impossible to carve and others were carved improperly. Those pieces could be reutilized to make the voussoirs and/or be used as rubble to infill walls, buttresses, etc.

The processes involved in this unusual endeavor for the $20^{\text {th }}$ century have revealed some of the techniques that master masons used to teach the art of stone carving to others. The presence of an experienced mason who could understand the operations necessary to achieve the desired forms in stone was crucial to accomplish the task. This experience revealed transfer of knowledge in the art of stone carving could be done by example. The education of an apprentice requires the progressive acquisitions of skills as it happens in other guilds and disciplines. Stonecutting for vaulting systems is based on practical geometry resulting in carved pieces such as tas-de-charge, bosses, keystone, intersections, ribs voussoirs, and web voussoirs. All of them carved in accordance to the ancient principles of stereotomy. Since the carving process for ribbed vaults needs to follow rigorous laws that guarantee the structural stability of arches, one can deduce that this teaching-learning process occurred in the sixteenth century did not provide too much room for improvisation or substantial changes (17). 
manga larga, pantalones y sombrero en la ilustración de Sahagún podría haber sido el maestro de obras de Europa que vino a enseñar a los canteros indígenas. Él está haciendo el trabajo más refinado y está enseñando con el ejemplo el arte de la cantería. El cantero indígena sentado al frente de él está trabajando en una pieza de forma regular, sugiriendo que podría tratarse de un aprendiz. Este ejercicio de la transmisión de conocimientos sobre la cantería no fue diferente a la forma en que los Europeos enseñaban a sus aprendices. Los canteros, como muchos otros gremios basados en trabajo artesanal, se han enseñado con el ejemplo, dejando que el aprendiz adquiera las habilidades gradualmente.

La ilustración en el libro de Sahagún es un testimonio vivo de la participación de los indígenas de México en las actividades de construcción. Es también la representación de la dinámica de trabajo que se generó en las obras de construcción durante el siglo XVI. Según ha explicado Alfredo López Austin, Sahagún se basa en la larga tradición de la escritura pictórica de las culturas precolombinas de México a fin de transmitir la información que considera importante (18). Los pictogramas fueron usados como medios de comunicación por las culturas mesoamericanas y Sahagún lo reconoce y en muchas ocasiones decide utilizar las ilustraciones en vez de la palabra escrita. La palabra pictórica del siglo XVI en México puede ser entendida como la descripción objetiva de los hechos históricos.

Después de ver los edificios de Mitla podemos reconocer que las estructuras de arcos y bóvedas fueron el elemento de construcción más ajeno a los canteros indígenas de México. A diferencia de los mayas, que desarrollaron la "bóveda maya" (basada en sillares de piedra que avanzan gradualmente hasta encontrarse) otras culturas de México no usaron la albañilería para construir el techo de edificios. No hay evidencia de culturas precolombinas que practicaran la construcción de arcos y bóvedas: la práctica común para la construcción de techos se basaba en estructuras planas hechas con vigas de madera añadiendo capas de barro y madera. Algunos otros edificios vernáculos de la época también se ilustran con techos inclinados de paja, que fueron apoyados con modestas armaduras de madera.

Una vez que los arcos y bóvedas fueron introducidos en el repertorio autóctono de elementos constructivos las tareas involucradas en la construcción de este tipo de estructuras debieron haber sido una tarea muy excitante para los albañiles indígenas. Como se ha mencionado antes, el uso de

\section{FROM STONE FRETWORK TO RIBBED VAULTS}

We have looked at the process of the reconstruction of the vault in Teposcolula, now we should look back to Figure 2. This $16^{\text {th }}$ century "canteros" illustration depicted in Sahagún's codex shows a scenario that has enormous similarities with the scenarios seen during the reconstruction of the vault during the end of the $20^{\text {th }}$ century. In accordance with the experience and the process we can suggest that the distinctive figure wearing long sleeve shirt, pants and hat on Sahagún's illustration could have been the master builder from Europe who came to teach the indigenous masons. He is doing the more refined work and is teaching by example the art of stonecutting. The indigenous mason who is seating in front of him is working on a piece of regular shape as well, and I can suggest that might be an apprentice. This exercise of knowledge transmission on stonecutting was not different to the form in which European master masons taught their apprentices. Stone carving, as many other guilds based on craftsmanship, are taught by example as the apprentice gains skills gradually.

The illustration in Sahagún's book is graphic testimony of the participation of the indigenous of Mexico in the construction activities. It is also the representation of the work dynamics involved in the construction sites during the early $16^{\text {th }}$ century. As explained by Alfredo López Austin, Sahagún relies in the long tradition of pictorial writing of the pre-Columbian cultures of Mexico in order to deliver the information he wants to convey (18). Pictographs were the communication media used by the Mesoamerican cultures and Sahagún chooses in many occasions to use the illustrations instead of the written words. The pictorial word of $16^{\text {th }}$ century Mexico can be understood as the factual description of the historic events.

After looking at Mitla's buildings we can recognize that arches and vaulted structures were the most foreign building element to the indigenous masons of Mexico. Contrary to the Mayans, who developed the "mayan vault" (based on stone corbelling), other cultures did not use masonry to confine the roof of their buildings. There is no evidence practice of arches and vaults construction in pre-Columbian cultures. The common pre-Columbian practice to construct roofs of was based on flat structures made with wood beams superimposing layers of mud and wood. Some vernacular domestic buildings of that time are also illustrated 
rueda utilizado como un artefacto de transporte esta aun en discusión. Por lo tanto, el círculo se dedicaba a la imagen que denotaba poder, comúnmente relacionadas con la religión y el estatus social. El arco, como elemento constructivo era completamente nueva para ellos y el proceso de forjar y colocar piedras en forma de cuña en forma circular debió haber sido un fenómeno que adquirió un significado simbólico. Este elemento de construcción podría haber ayudado a los monjes para motivar a los caciques a incitar la participación ciudadana en la contratación de los proyectos. Los indígenas fueron sin duda cautivados por las nuevas estructuras y los caciques se entusiasmaron con la idea de construir estos "espectaculares" templos. Inclusive se puede sugerir que los gobernantes locales vieron estos templos como representaciones de su nueva condición social y su legado a la sociedad en transformación.

Al observar los métodos de construcción precolombinos y las tareas prácticas que intervienen en la talla de piedra de arcos y bóvedas, podemos concluir que la transferencia de tecnología de la construcción de Europa a las Américas en el siglo XVI se limitó a la construcción de sistemas abovedados y a la construcción de estructuras de mampostería basadas en el arco (Figura 17). Esta transferencia no se logró a través de documentos escritos, sino a través de la experiencia. Este proceso debe de haber asumido una serie de métodos de enseñanza bilingüe basado en la geometría práctica y la enseñanza se llevó a cabo en entornos donde había un maestro y varios aprendices. Las características de los edificios y sus sistemas de bóvedas requirieron especialistas que se formaron poco a poco entre 1550 y 1580 . Este grupo experto de canteros fue capaz de comprender la naturaleza la piedra y fue capaz de lograr un trabajo cantería muy sofisticado (Figura 18). La medida en que las manos de los indígenas mexicanos marcaron una diferencia en el proceso de labrado de piezas para bóvedas debió haber sido muy poca. Sin embargo, los pueblos indígenas deben haber tenido un enorme impacto en los procesos que involucrados en la construcción, tales como la extracción de piedra, el transporte y la logística de operación. Su conocimiento de la ubicación del banco de cantera, como minería y tallado de piedra, y la capacidad de organización fue esencial para llevar a cabo esfuerzos de tal magnitud. La combinación de este conjunto de habilidades y métodos de construcción europea permitió dominar la nueva tecnología a los canteros locales, logrando un rendimiento de alta calidad, excepcional en la construcción de sofisticadas bóvedas de crucería. with pitched hay roofs, which were supported with modest wood trusses.

Once arches and vaults were introduced to the indigenous repertory of constructive elements the tasks involved in the construction of arch-based structures should have been an exciting enterprise for the indigenous masons. As mentioned before, the use of wheels used as a transportation artifact or as a device for specific purposes is debatable. Thus, the circle was constricted to iconic ideas linked to religion, power, and social status. They arch, as a constructive element was completely new for them and the process of carving and placing wedge shaped stones together in circular form should have been a phenomenon that acquired symbolic meaning. This building element might have helped the monks to motivate the caciques in recruiting citizen participation in the projects. The natives were certainly captivated by the new structures and the caciques enticed them with the idea of constructing these spectacular temples. One can even suggest that local rulers foresaw these temples as representations of their new status and their legacy to the transforming society.

By looking at pre-Columbian methods on construction and the practical tasks involved in stone carving for arched structure we can conclude that the transfer of building technology from Europe to the Americas in the $16^{\text {th }}$ century was limited to the construction of vaulting systems and construction of spanning masonry structures based on the arch (Figure 17). This transference was not achieved through written documents but through practice. This process must have assumed a series of bilingual teaching methods based on practical geometry, education of carving methods was conducted in master-apprentice environments. The characteristics of the buildings and their vaulting systems required specialists who were slowly formed between 1550 and 1580. This skillful group of masons was capable of understanding the nature of the material and was able to accomplish sophisticated stonecutting work (Figure 18). The extent to which Mexican hands made a difference in the manufacturing process of vaults' pieces was minimal. Nevertheless, the indigenous people must have had an enormous impact in the processes involved in the construction such as stone mining, transportation, and operation logistics. Their knowledge of quarry location, mining and carving stone, and the organization ability was essential to accomplish endeavors of such substantial magnitude. The combination of these set of skills and 
Las condiciones para realizar estos grandes edificios en un período de tiempo relativamente corto fueron tres: la organización social de las comunidades mexicanas en la llegada de los españoles, el establecimiento de nuevos asentamientos, y la existencia de mano de obra calificada. La combinación de estos tres componentes proporcionó un entorno adecuado para la construcción de edificios monumentales. Hubo una estrecha participación de los pueblos indígenas relacionados con el diseño y la construcción y hubo una gran movilización de la gente, una gran actividad de construcción en la región que puede ser comparable a otras grandes empresas llevadas a cabo por civilizaciones históricas de todo el mundo.
European building methods allowed the indigenous masons to master the new technology, achieving an outstanding highquality performance in the construction of sophisticated ribbed vaults.

The conditions present in accomplishing these large buildings in a relatively short period of time were threefold: the social organization of the Mexican communities at the Spanish arrival, the establishment of new settlements, and the existence of skilled labor. The combination of these three components provided a suitable environment for construction of these monumental buildings. There was close involvement of the indigenous people related to the design and construction and there was a vast mobilization of people, a huge construction activity in the region that can be comparable to other great enterprises carried out by historic civilizations around the globe.
17. Bóvedas de la iglesia de Santo Domingo Oaxtepec construidas en el siglo XVI en Morelos, México.

17. Vaults of the sixteenth-century church of Santo Domingo Oaxtepec in Morelos, Mexico.

18. Bóvedas del claustro del siglo XVI en Santo Domingo Yanhuitlán, Oaxaca, Mexico.

18. Vaults of the sixteenth-century cloister of Santo Domingo Yanhuitlán in Oaxaca, Mexico.

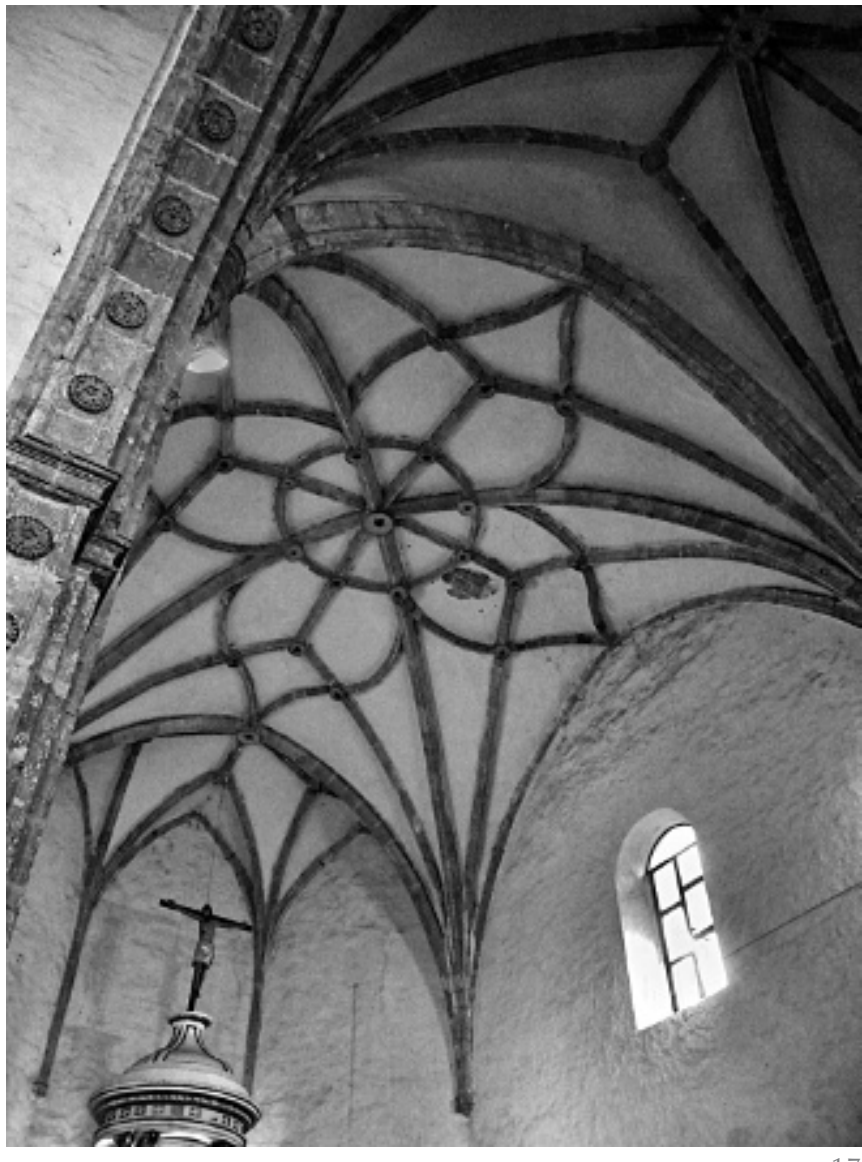

17

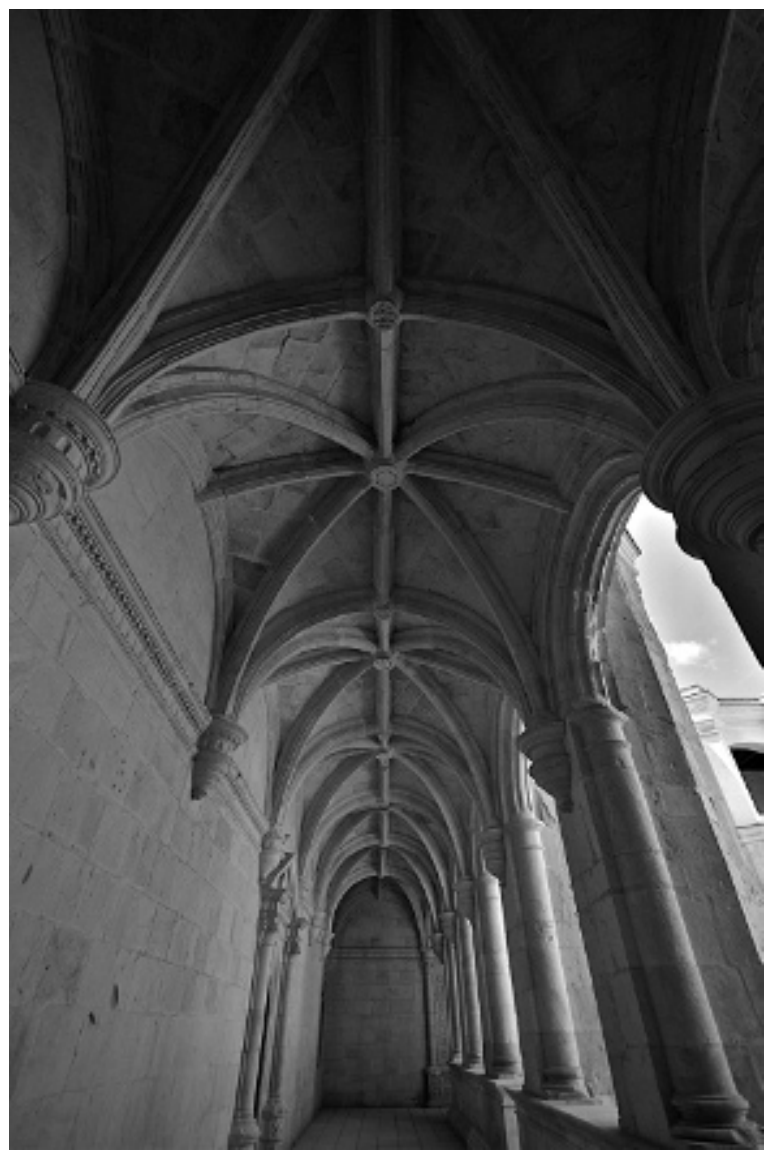

\section{REFERENCIAS / REFERENCES}

(1) Sahagún, Bernardino (1578). Códice Florentino (Historia general de las cosas de la Nueva España). Facsimil del original: México, Secretaría de Gobernación (1979).

(2) Baird, Ellen T. (1987). Sahagún's Codex Florentino: The Enigmatic A. Ethnohistory, Vol. 34, No. 3: 288-306. Duke University Press.

(3) Terraciano Kevin (2004). The Mixtecs of Colonial Oaxaca. Stanford University Press. pp. 10-19. 
(4) Huerta, Santiago (2004). Arcos, bóvedas y cúpulas. Geometría y equilibrio en el cálculo tradicional de estructuras de fábrica. Madrid, Instituto Juan de Herrera. pp. 29-34.

(5) Holmes, William (1895). Archaeological Studies among the Ancient Cities of Mexico. Chicago, Field Museum of Natural History. Anthropological Series 1.

(6) Marquina, Ignacio (1951). Arquitectura Prehispanica. Instituto Nacional de Antropología e Historia, Mexico. pp. 264-266

(7) Robles, Nelly (1994). Las canteras de Mitla, Oaxaca: tecnología para la arquitectura monumental. Nashville Tenn, Vanderbilt University. Series: Vanderbilt University publications in anthropology, No. 47.

(8) Spores, Ronald et al. (2012). Report on archeological exploration in the zone called "Pueblo Viejo" near Teposcolula. Complete report is found on www.fahho.org (Consulted July 25th 2012).

(9) Kubler, George (1982). Arquitectura Mexicana del Siglo XVI. Fondo Cultura Económica. México.

(10) Romero-Frizzi, Angeles (1996). El sol y la cruz: los pueblos indios de Oaxaca colonial. Ciesas.

(11) López Villaba, José Miguel (2006). Los fueros y ordenanzas medievales: embrión del gobierno de los cabildos hispanoamericanos. Historia, instituciones, documentos, No. 33: 339-363.

(12) Wyrobisz, Andrzej (1980). La ordenanza de Felipe II del año 1573 y la construcción de ciudades coloniales españolas en la América. Estudios Latinoamericanos, 7: 11-34.

(13) Kiracofe, Joseph (1995). Architectural Fusion and Indigenous Ideology in Early Colonial Teposcolula. The Casa de la Cacica: A building at the Edge of the Oblivion. Anales del Instituto de Investigaciones Estéticas. No 66.

(14) Baird, Anthony (1962). The Churches of México 1538-1810. Berkeley.

(15) Spores, Ronald et al. (2006). Informe final al Consejo de Arqueología del INAH de la tercera temporada del Proyecto Teposcolula Yucundaa. INAH, México.

(16) Ibarra, Benjamin (2007). Restauración de la bóveda de la capilla abierta de Teposcolula en Oaxaca, México. Loggia: Arquitectura y Restauración, No 20: 98-111.

(17) Ibarra, Benjamin (2012). Transmission of Building Technology from Europe to the Americas: Underlying Geometry and Stereotomy Studies of Three Ribbed Vaults Constructed in Mexico between 1535 and 1575. Nuts and bolts of History of Construction. Vol. II: 393-400. Paris, Picard.

(18) López Austin, Alfredo (1974). The research method of Fray Bernardino de Sahagún. Sixteenth Century Mexico. Albuquerque, University of New Mexico press. pp. 111-148. 